\title{
A STUDY ON GROWTH OF DIGITAL INDIA CAMPAIGN
}

\author{
Manish Gulyani \\ Department of Management Studies \\ Panipat Institute of Engineering \& Technology, \\ Samalkha \\ Chankel Pasricha \\ Department of Management Studies \\ Panipat Institute of Engineering \& Technology, \\ Samalkha
}

\begin{abstract}
Today is time for Education 4.0 and flip based learning where students have access to technological resources. Digitalization is need of today's world. Digital India was launched by government of India in 2015 to transform India into a knowledgeable economy and digital world. This aims at connecting rural areas with high speed networks. It would ensure government services are available to citizens electronically and delivering good governance. Digital India ensures all resources accessible in regional languages and providing Government certificates and documents available on the cloud with portability. The objective of paper is to know impact, challenges of digital India on all aspects of governance and improvement in quality of life of citizens.
\end{abstract}

(Keywords: Digital, Governance \& Cloud)

\section{INTRODUCTION}

The Digital India drive is a dream project of the Indian Government to transform India into a knowledgeable economy and digital society with good governance for citizens. The programme launched on 1 July 2015 by Prime Minister Narendra Modi to make Government services available to people digitally and enjoy the benefit of latest information and innovations in technology aspects. Digital Technologies which includes mobile applications and cloud computing emerged as boon for economic growth and citizen empowerment. This initiative will ensure that all Government services and information are available anywhere, anytime and on any device. Digital India helped in achieving objectives of Education \& information to all. Various schemes like Digital Locker, e-education, e-health, esignature and National scholarship portal are available to citizens. Government also launched a

\author{
Paras Batra \\ MBA Student \\ Panipat Institute of Engineering \& Technology, \\ Samalkha \\ Chakshu Goel \\ MBA Student \\ Panipat Institute of Engineering \& Technology, \\ Samalkha
}

digital locker under the name of "Digi Locker". It aims at minimization of physical documents and enables sharing of e-documents across various agencies.

\section{LITERATURE REVIEW}

Review of literature provides the information of research work done already by various researchers done in this field. A number of research papers and articles provide a detailed insight about the role of Digital India and implications of this project in India.

(1) Sharma et al. (2015) in his study concluded that Digi Locker generates stores and processes data in virtual central repository and is easy to access anytime, anywhere, through established protocols which create a transparent environment. Digital technologies which includes mobile applications and cloud computing acts as a boon for shaping our lives.

(2) Jain et al. (2016) made a study and described that in this project every citizen has a bright prospect to transform the lives in many ways that were hard to envision couple of years ago. In his opinion more prospects have been opened for youth which will boost Indian economy.

(3) Garg and Tschang (2017) in their study states that through this initiative procedures can be made more efficient and smoothes the flow of information, tracking records and performance. When basic information is stored in digital form, it provides the opportunity for easier access to that information by citizens.

(4) Tyagi et al. (2018) in his study concluded that IT can increase transparency and accountability, simply 
by requiring information, such as basic complaints, to be logged completely and systematically.

(5) Muthulakshmi and Kamatchi (2019) in her paper entitled that all digital services requires knowledge that go beyond the basic definition of ITenabled services, and have all benefited from the change in management approach within the IT sector.

\section{OBJECTIVES OF THE STUDY}

(1) To find out the impacts of implementing this scheme.

(2) To what extent today's aspiring youth are aware about Digital India Initiative.

\section{RESEARCH METHODOLOGY}

To make research a success, one has to define and plan whole programme properly and effectively. The research methodology is descriptive in nature and data is collected from primary and secondary resources.

\section{(1) Sample Design: Convenience sampling}

(2) Sample Size: 200 respondents

(Questionnaire was designed of 10 questions and shared in form of Google form to respondents)

\section{Data Analysis and Interpretation}

Total numbers of male respondents are 116 and female respondents are 84 .

Question 1: Are you aware about Digital India?

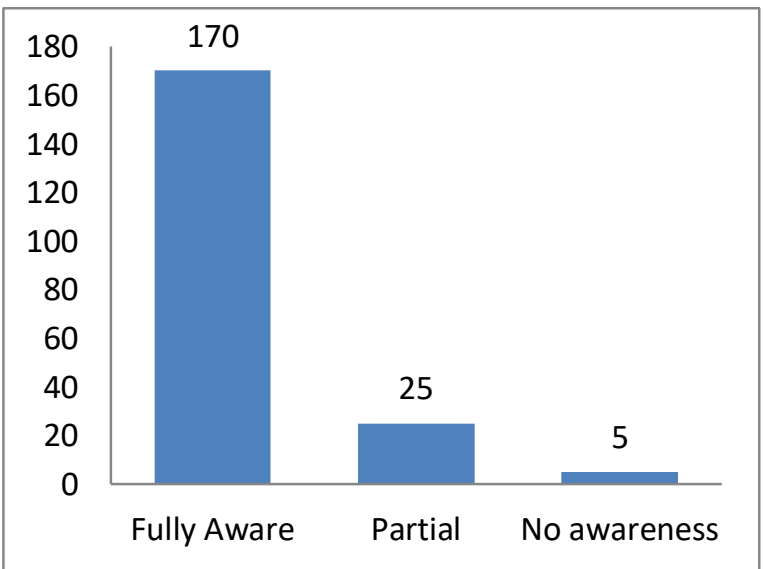

Number of respondents who were fully aware about this initiative are 170 and 25 respondents were having partial knowledge about Digital India. Whereas 05 respondents don't have any knowledge about this scheme.

Question 2: Have you availed any service of Government of India under Digital India mission?

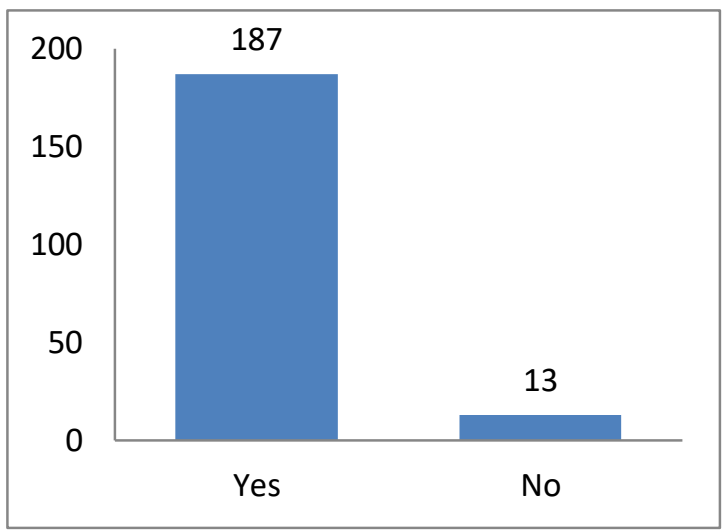

187 respondents have used services whereas 13 said that they have never used any service.

Question 3: Do you think Digital India will be successful in coming years?

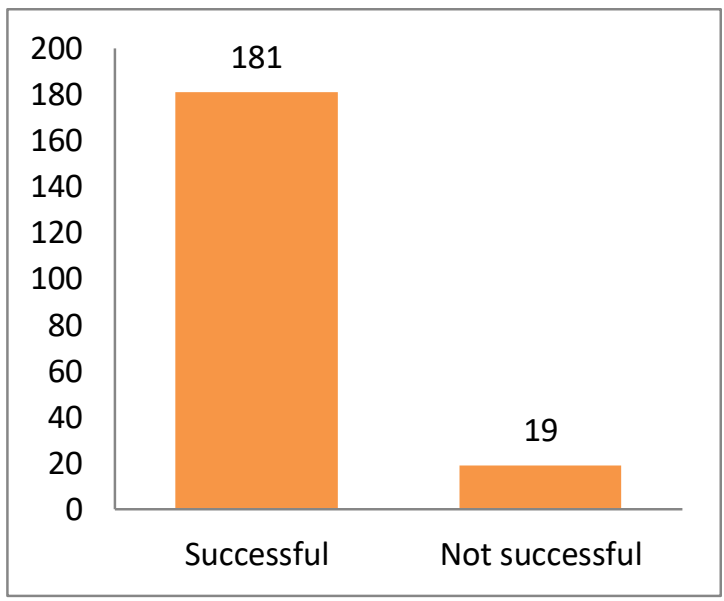

181 respondents are in favors of this question whereas 19 respondents said that it will not be successful because in so many remote areas of India, there is still network problem.

Question 4: Do you think Digital India promotes good governance and brings transparency in system? 


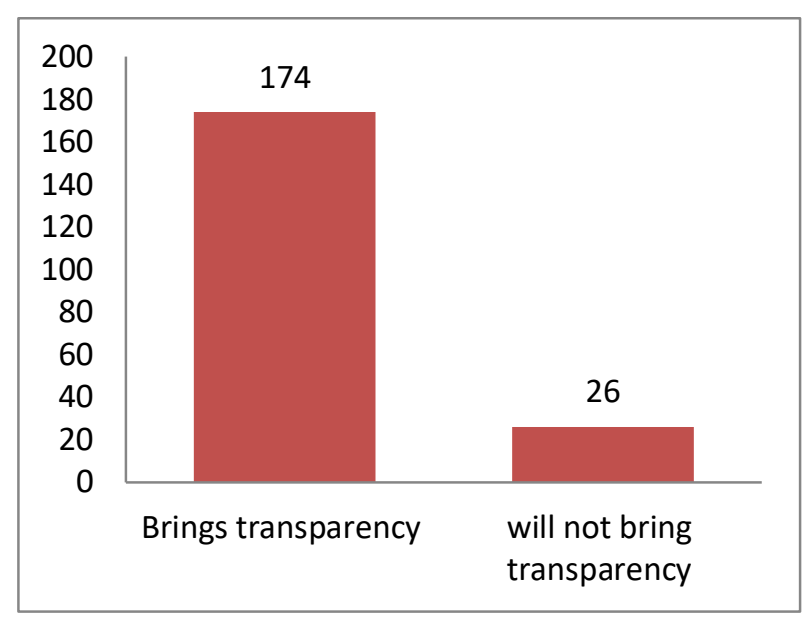

174 respondents agreed with this statement and concluded that in many departments of government fee transactions proceeds online so there is no chance of corruption and transparency has promoted whereas rest 26 respondents argued that some services are not available on digital platform so there lacks some transparency.

Question 5: Are there any issues created while using services provided on Digital platform?

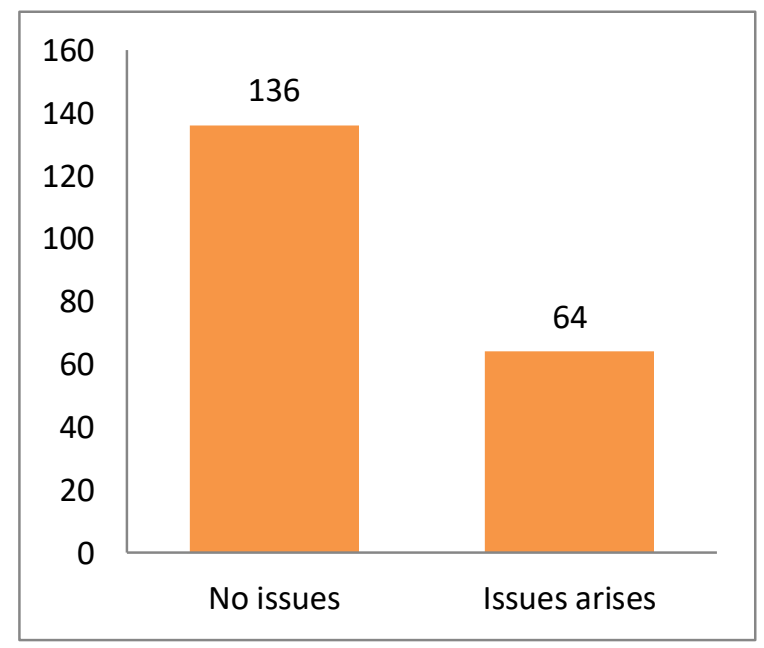

136 respondents replied that services available on digital platform work with smoothness whereas rest 64 respondents are not in favors. They concluded that sometime user not able to understand instructions how to precede further, on the other hand few times network issues were there which leads to delay in work.

Question 6: What are the Digital Services you have used and what's your experience?

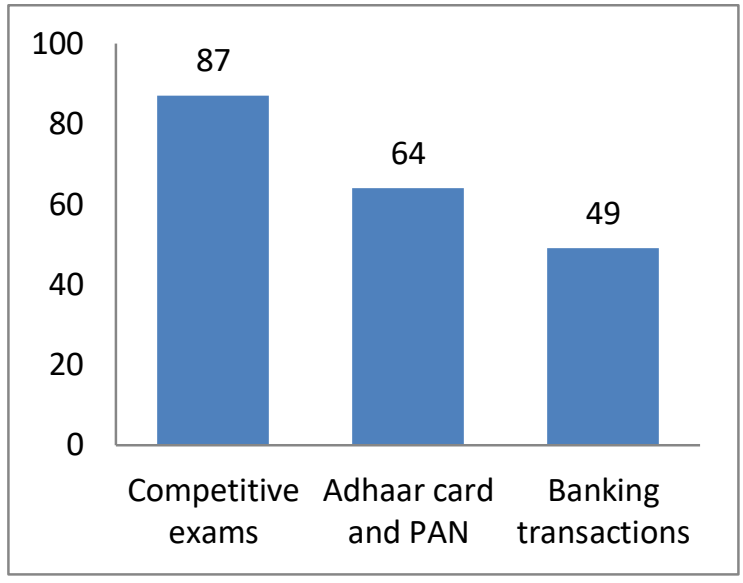

87 respondents who were in final year of masters praised this service because they appear in many competitive exams and they easily able to download their admit cards through this digital campaign, 64 respondents said they have availed services of generating Aadhaar card and PAN card through this digital platform and they were satisfied. Rest 49 respondents praised that due to this initiative digital banking comes into picture. Now a day's people are using digital means of payment like NEFT, RTGS and IMPS through which time have been saved and they concluded that Digital India promotes Cashless Economy.

Question7: Will this Digital India helps in changing Business Environment of India?

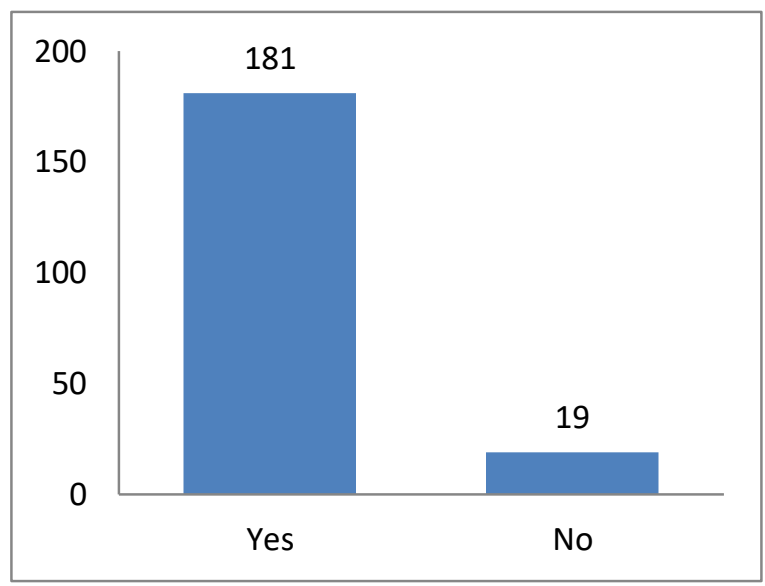

181 Respondents are in favors of this question they said that during this lockdown period in order to save our self many people don't go to bank for withdrawal unless there is a need of huge cash. Everyone has done payments through mobile applications like Paytm, BHIM and UPI. All these platforms were 


\section{International Journal of Engineering Applied Sciences and Technology, 2020 Vol. 5, Issue 2, ISSN No. 2455-2143, Pages 222-225 \\ Published Online June 2020 in IJEAST (http://www.ijeast.com)}

given more focus when demonetization and Digital India comes into picture and they said that all these initiatives will improve the rank of "Ease of doing business" that will bring more foreign direct investment in our India. Rest 19 respondents were not in favors of this. They concluded that many people in India are still living in remote areas and unable to operate and access to mobile applications. For them these applications are of no use.

\section{CONCLUSION}

With the imminent of "Digital India" campaign, India will have a heavy and powerful digital infrastructure. It aims at bringing transparency and governance, universal phone connection, creating jobs and Digital inclusion, e-services, Digital locker system, eeducation and e-health which helps in making India to be pioneer in IT use solution. More employments prospects will open for the youth that will boost the nation's economy. Although Digital India programme is facing some difficulties, yet it has great impact on India to make the best future of every citizen. We Indians have to fight together to tackle this situation of COVID 19 to shape the Indian economy. Let us look all forward and join hands for the successful implementation of this project.

\section{REFERENCES}

1. Available at: http://en.wikipedia.org/wiki/Digital India

2. Available at: http://economictimes.indiatimes.com/tech/internet/di gital-india15-salient-things-to-know-about-pmnarendra-modisproject/article/47893380.ece

3. The Hindu. (2016, July 29). The Hindu Business line InfoTech. Retrieved from
Thehindubusinessline.com: www.thehindubusinessline.com/infotech/digitisation-will-change-economic-growth$\underline{\text { model-nilekani/article8918146.ece }}$

4. Digital India, Power to Empower: Department of Electronics \& Information Technology, Ministry of Communications and Information Technology, Government of India, Design and Published by: National e-Governance Division $4^{\text {th }}$ floor, Electronics Niketen, 6 CGO Complex, lodhi Road, New Delhi 110003, 2015, (pp. 1-79).

5. Sharma, N. (2015). E-KRANTI- ELECTRONIC DELIEVERY OF SERVICES. Developing Indian Economy through digital transformation (pp. 234235).

6. Jain, K. (2016). Development of Smart cities in India-Dream to Reality, International Journal of Business Policy \& Governance, (pp. 76-78).

7. Tyagi, P. (2018). A Study on diffusion of digital locker technology in India, Developing Digital Indian Economy (pp. 145-148). Ahmedabad: Gujarat Technological University.

8. Garg Vikas and Tschang Shalini (2018). "Role of Information Technology in Digital India" (pp. 334$335)$.

9. Muthulakshmi Geeta and Kamatchi Bharat (2019). "The thought behind the Digital India: IT based software's and platform" (pp. 231-233).

10. The Boston Consulting Group, Internet and Mobile Association of India. (2017). India@Digital Bharat Mumbai: The Boston Consulting Group.

11. http://egovernance.in/new/digital indiaachievements-concerns. 